DOI: https://doi.org/10.47405/mjssh.v6i7.919

\begin{tabular}{|c|c|}
\hline & Malaysian Journal of Social Sciences and Humanities (MJSSH) \\
\hline Malaysian Journal of & Volume 6, Issue 7, July 2021 \\
\hline (Mun-sSH) & e-ISSN : 2504-8562 \\
\hline & $\begin{array}{l}\text { Journal home page: } \\
\text { www.msocialsciences.com }\end{array}$ \\
\hline
\end{tabular}

\title{
Penerapan Kefahaman Nilai Interaksi dalam Menangani Sikap Ekstrem Ke Arah Mewujudkan Keharmonian Hubungan Etnik di Malaysia
}

\author{
Wan Zulkifli Wan Hassan 1, 2 \\ 1Pusat Citra Universiti, Universiti Kebangsaan Malaysia (UKM) \\ ${ }^{2}$ Institut Islam Hadhari, Universiti Kebangsaan Malaysia (UKM) \\ Correspondence: Wan Zulkifli Wan Hassan (drwanzul@gmail.com)
}

\begin{abstract}
Abstrak
Kepelbagaian etnik perlu diurus dengan sempurna dan ia sekali gus menjadi faktor penting untuk mewujudkan hubungan etnik yang erat dalam kalangan rakyat Malaysia. Hal ini akan menentukan suasana hubungan etnik yang lebih baik pada masa hadapan. Antara perkara yang perlu diambil perhatian adalah dengan melihat persoalan tentang bagaimana kefahaman masyarakat terhadap nilai interaksi yang sebenar supaya dapat dijadikan penyelesaian dalam segala bentuk permasalahan masyarakat pelbagai etnik. Aspek yang sering kali dihadapi oleh sebahagian pemikiran masyarakat ialah kefahaman mereka tentang nilai interaksi yang digalakkan dan apakah perkara yang boleh dikongsi bersama dengan masyarakat berlainan etnik, agama dan budaya. Ketidakfahaman masyarakat sendiri mengenai nilai interaksi yang sebenar khususnya dalam konteks agama dan kepercayaan tertentu sering kali membawa mereka menjauhkan diri daripada masyarakat pelbagai agama, etnik dan budaya. Ada yang bersikap ekstrem dan mengambil jalan sukar dalam memahami nilai interaksi yang sebenar kerana tidak mengetahui akan kewujudan kelonggaran dan toleransi dalam kes-kes tertentu.. Kajian ini akan dilaksanakan berdasarkan soal selidik secara atas talian (online) dalam kalangan responden yang pernah didedahkan tentang nilai interaksi sebenar seramai 554 orang responden. Data yang dipungut, dianalisis dan dikodkan secara kuantitatif dengan menggunakan teknik SPSS terhadap soal selidik yang dijawab oleh responden. Ini membolehkan pengkaji memahami dengan lebih mendalam terhadap isu yang dikaji. Kajian mendapati majoriti masyarakat memahami tentang nilai interaksi sebenar dalam mewujudkan keharmonian hubungan etnik di Malaysia. Hal ini dilihat tidak memberi kesan yang buruk kepada masyarakat pelbagai etnik. Ia sekali gus menggambarkan kefahaman tentang nilai interaksi dapat membendung sikap ekstrem dalam kalangan masyarakat. Dapatan kajian mendapati nilai pegangan agama yang kuat boleh memandu mereka dalam mewujudkan interaksi yang antara sesama manusia, nilai simpati terhadap orang lain meskipun berlainan bangsa, etnik dan agama, sifat pemaaf, mempunyai persepsi positif terhadap orang lain, sikap toleransi dengan kaum yang lain, sayangkan keharmonian dalam sesebuah negara dan hormat nilai warisan dan agama rasmi negara
\end{abstract}

Kata kunci: nilai interaksi, ekstrem, keharmonian, hubungan etnik, Malaysia

\section{Application of Understanding the Value of Interaction in Addressing Extreme Attitude Towards Creating Harmony of Ethnic Relations in Malaysia}

\section{Abstract}


Ethnic diversity needs to be properly managed and it is an important factor in establishing a strong ethnic relationship among Malaysians. This will determine the atmosphere of better ethnic relations in the future. Among the things that need to be considered is to look at the question of how the society understands the real value of interaction so that it can be solved in all forms of problems of the multiethnic society. The aspect that is often faced by some people's thinking is their understanding of the value of promoting interconnection and what can be shared with ethnic, religious, and cultural communities. People's own incomprehension about the true value of interactions especially in the context of certain religions and beliefs often leads them to distance themselves from the various religious, ethnic, and cultural communities. Some are extreme and take a difficult path in understanding the true value of interactions because they do not know the existence of flexibility and tolerance in certain cases. This study will be conducted based on an online questionnaire among respondents who have been exposed to the actual interaction value of 554 respondents. Data collected, analysed, and encoded in a quantitative manner using SPSS techniques against questionnaires answered by the respondent. This enables the reviewer to better understand the issues under review. The study found that most of the community understands the value of real interaction in creating harmony of ethnic relations in Malaysia. This is seen to have no adverse impact on the multi-ethnic community. It also described an understanding of the value of interactions that can stem extreme attitudes among society. The findings found that strong religious values can guide them in creating interactions between people, the value of sympathy for others despite different races, ethnicities, and religions, forgiving nature, positive perception of others, tolerance with other races, love harmony in a country and respect the value of the national heritage and official religion.

Keywords: value of interaction, extreme, harmony, ethnic relations, Malaysia

\section{Pengenalan}

Isu-isu yang sering kali dibangkitkan dalam hubungan etnik di Malaysia ialah berkisar ketaksuban kepada etnik masing-masing iaitu mengenai unsur-unsur etnosentrisme, stereotaip, prejudis dan diskriminasi. Menurut Shamsul Amri (2012) pola hubungan etnik di Malaysia sejak tahun 1946 hingga kini memperlihatkan pola turun naik dalam hubungahn etnik, tetai pada amnya keadaan di Malaysia adalah aman damai dengan hubungan etnik yang harmoni.

Walau bagaimanapun kadang-kadang beberapa keadaan wujud suasana yang kurang sihat sehingga boleh menimbulkan konflik dalam masyarakat Malaysia yang bersifat majmuk sehingga menyebabkan berlakunya kerenggangan hubungan antara etnik dan agama. Dalam pada itu terdapat segelintir masyarakat Islam yang mengasingkan diri daripada masyarakat berlainan etnik dan agama kerana ingin memelihara kesucian agama mereka atas alasan yang remeh seperti tidak mahu berkongsi gelas yang digunakan oleh etnik dan penganut agama yang lain. Selain itu ada yang mengambil inisiatif untuk menawarkan perkhidmatan dobi mesra Muslim yang tidak membenarkan mereka yang bukan Muslim

Oleh itu, mereka sewajarnya memerlukan panduan yang tertentu bagi mengamalkan suatu budaya yang boleh mewujudkan suasana yang harmoni dan sejahtera. Permasalahan yang melibatkan hukum perlu diperjelaskan kepada masyarakat agar segala tindak-tanduk mereka dalam berinteraksi dengan masyarakat bukan Muslim bersuluh hidayah. Ini kerana kebanyakan mereka bertindak di luar batas ilmu bahkan lebih bersifat persepsi yang terhasil dari cakap-cakap orang awam yang juga jahil tentang hukum-hakam agama. Persoalan fiqh interaksi antara Muslim dengan bukan Muslim agak kurang dibicarakan secara tersusun dan terhimpun oleh sarjana Islam tradisi dan kontemporari.

Kajian ini diharapkan dapat memberi gambaran sebenar permasalahan yang dihadapi oleh masyarakat Islam dalam masalah hukum-hakam yang melibatkan interaksi mereka dengan keluarga bukan Islam dan ruang penyelesaian. Justeru kefahaman tentang nilai interaksi adalah satu konsep pendekatan yang baik dalam usaha mewujudkan keamanan dan kestabilan sosial dalam sesebuah negara. Penekanan 
terhadap nilai ini diambil sebagai suatu pendekatan kesejahteraan dan keharmonian dalam pembangunan masyarakat di Malaysia.

Pendekatan ini adalah dilihat bersesuaian dengan pendirian Malaysia sebagai negara progresif, harmoni dan menolak sebarang bentuk eksterimis sehingga menyebabkan berlakunya keganasan. Kefahaman terhadap nilai interaksi dianggap medium yang amat sesuai untuk diketengahkan dalam kalangan masyarakat Islam yang berbilang kaum. Dengan ini, keharmonian masyarakat Malaysia akan menjadi lebih aman dan sejahtera. Diharap dengan penerapan kefahaman terhadap nilai interaksi mampu memberi satu garis panduan kepada masyarakat khususnya yang beragama Islam agar mengambil langkah yang lebih proaktif ke arah membawa masyarakat Malaysia mencapai keharmoniaan yang seimbang.

\section{Permasalahan Kajian}

Rakyat Malaysia yang terdiri daripada pelbagai etnik, begitu beriltizam ke arah mengukuhkan semangat perpaduan dan integrasi antara etnik dan wilayah. Ini penting bagi menjamin kelangsungan Malaysia sebagai sebuah negara yang berbilang etnik dan mempunyai wilayah yang terpisah di antara negeri-negeri. Kepelbagaian etnik ini menunjukkan bahawa isu-isu bahasa, agama, kedudukan istimewa orang Melayu dan kedudukan Raja-Raja Melayu menjadi faktor penting untuk mewujudkan hubungan etnik yang erat dalam kalangan rakyat Malaysia. Isu-isu ini menurut Ratnam (1969), akan menentukan suasana hubungan etnik pada masa hadapan dengan melihat bagaimana persoalan mengenai kedudukan istimewa orang Melayu, agama dan bahasa diselesaikan.

Aspek yang sering kali menghantui pemikiran masyarakat bukan Islam ialah soal hukum-hakam atau pantang larang agama Islam yang tidak membenarkan penganutnya melakukan perkara yang boleh dikongsi bersama dengan masyarakat Islam. Ketidakfahaman masyarakat Islam sendiri mengenai hukum-hakam Islam sering kali membawa mereka menjauhkan diri daripada masyarakat pelbagai agama, etnik dan budaya.

Ada yang bersikap ekstrem dan mengambil jalan sukar dalam masalah hukum kerana tidak mengetahui akan kewujudan kelonggaran dalam kes-kes tertentu. Memandangkan begitu kurangnya bimbingan keagamaan kepada sebahagian masyarakat Islam, sering kali pengetahuan mereka mengenai hukum interaksi antara Muslim dan bukan Muslim didasari oleh adat kebiasaan budaya Melayu bukan berdasarkan ilmu yang sebenar. Hukum- hakam Islam yang difahami melalui jalan tersebut kadangkala tidak bersandarkan kepada dalil syarie yang muktabar dan lebih kepada tanggapan sahaja.

Kajian awal mendapati masyarakat Islam menghadapi pelbagai kekeliruan dan masalah kehidupan yang datang dari pelbagai pihak, sama ada daripada masyarakat bukan Muslim ataupun masyarakat Muslim lain dan juga masalah yang dicetuskan dari perubahan hidup yang berlaku dalam masyarakat. Titik awal permasalahan bermula apabila mereka berada di persimpangan untuk mengekalkan keharmonian hidup bersama masyarakat pelbagai agama, etnik dan budaya serta berdepan dengan dilema memahami Islam dan menyesuaikan diri dengan persekitaran budaya dan cara hidup Muslim (Osman, 2008; Karin, 2006; Carol, 2001; Ali, 1996).

Dalam konteks hubungan etnik di Malaysia, perkara-perkara yang dianggap menguntungkan orang Melayu dalam Perlembagaan Persekutuan diimbangi dengan peruntukan lain yang juga memberi kelebihan kepada etnik bukan Melayu. Perkara yang menetapkan Islam sebagai agama bagi persekutuan diimbangi dengan peruntukan kebebasan bagi setiap rakyat untuk menganut dan mengamalkan apa-apa agama dalam suasana aman dan harmoni. Begitu juga perkara yang menetapkan bahasa Melayu sebagai bahasa kebangsaan juga diimbangi dengan peruntukan bahawa tidak ada seorang pun yang boleh dilarang daripada menggunakan (melainkan bagi maksud rasmi) atau mengajar atau mempelajari apa-apa bahasa lain. Hal yang sama juga berlaku ke atas perkara yang menetapkan kedudukan istimewa orang Melayu dan bumiputera Sabah dan Sarawak diimbangi dengan 
peruntukan bahawa kerajaan tidak boleh melucut, menarik balik atau menyebabkan hak kaum lain terhakis.

Persoalan yang sering timbul dalam pemikiran masyarakat Islam apabila berinteraksi dengan mereka yang bukan Islam melibatkan pelbagai aspek kekeluargaan seperti politik, kejiranan, masalah makan minum, sambutan perayaan, nasab keturunan, batasan aurat, pewarisan harta pusaka dan lain-lain.

Walaupun persoalan tersebut sebahagiannya telah diketahui hukumnya, namun bagi sebahagian masyarakat, ini merupakan persoalan baru yang masih menjadi tanda tanya. Memberi jawapan yang relevan dan mudah tanpa mengetepikan aspek syariah amat diperlukan oleh masyarakat Islam. Masyarakat bukan Muslim juga perlu mengetahui alasan dan sebab kenapa Islam tidak membenarkan sesuatu perkara dilakukan oleh masyarakat Islam agar tidak menimbulkan salah faham dan mencetuskan persengketaan.

\section{Persoalan Kajian}

Justeru, kajian tentang fiqh interaksi amat perlu diketengahkan sebagai kajian ilmiah dengan mengambil kira permasalahan sebenar di lapangan. Persoalan kajian menjurus kepada:

i. Bagaimana kefahaman masyarakat khususnya yang beragama Islam di Malaysia mengenai kefahaman tentang nilai interaksi dengan masyarakat pelbagai agama, etnik dan budaya?

ii. Apakah permasalahan sebenar masyarakat yang boleh menggugat kehidupan hidup keharmonian bermasyarakat dalam berinteraksi dengan masyarakat pelbagai agama, etnik dan budaya khususnya yang berkaitan dengan sosial?

iii. Apakah nilai interaksi sebenar yang boleh diaplikasikan dalam masyarakat majmuk Malaysia yang bersifat pelbagai agama dan kaum yang kesannya mampu memantapkan lagi semangat perpaduan dan mengekalkan keharmonian?

\section{Objektif Kajian}

i. $\quad$ Mengenal pasti kefahaman dan amalan masyarakat Islam di Malaysia mengenai fiqh interaksi dengan masyarakat pelbagai agama, etnik dan budaya.

ii. Mengkaji permasalahan sebenar masyarakat Islam yang boleh menggugat kehidupan hidup keharmonian bermasyarakat dalam berinteraksi dengan masyarakat pelbagai agama, etnik dan budaya khususnya yang berkaitan dengan konteks sosial.

iii. Membangunkan nilai interaksi yang boleh diaplikasikan dalam masyarakat majmuk Malaysia yang bersifat pelbagai agama, etnik dan budaya sebagai usaha memantapkan lagi semangat perpaduan dan mengekalkan keharmonian.

\section{Kajian Perpustakaan}

Secara umumnya, kajian lepas mengenai fiqh interaksi antara Muslim dengan bukan Muslim lebih kepada kajian kepustakaan semata-mata tanpa mengambil kira permasalahan sebenar masyarakat Islam khususnya dalam kalangan mualaf yang masih berinteraksi secara aktif dengan keluarga dan ahli masyarakat asal mereka yang bukan Muslim.

Antara penulis yang menyentuh tentang kefahaman tentang nilai interaksi antara Muslim dan bukan Muslim ialah karangan Prof. Dr. Yusof al-Qaradawi dalam bukunya: Fi Fiqh al-Aqalliyat alMuslimah. Dar al-Syurouk (2001). Dalam buku tersebut beliau membincangkan persoalan hukum yang melibatkan masyarakat minoriti Muslim di tengah masyarakat bukan Islam. Beliau juga menerangkan tentang metode berfatwa yang sepatutnya diambil oleh para ulama dalam membicarakan hukum yang berkaitan dengan masyarakat minoriti Muslim. Menurut beliau para ulama sepatutnya 
mencari jalan mudah dan mengiktiraf hajat dan dharurat dalam berfatwa tanpa terlalu terikat dengan mazhab tertentu.

Walaupun begitu beliau tidak memperincikan semua permasalahan fiqh yang berkaitan dengan hubungan antara masyarakat minoriti Muslim dengan masyarakat bukan Islam dan memadai dengan memberi beberapa contoh permasalahan fiqh sahaja.

Mohammad Nidzam (2009) dalam Fiqah Berinteraksi dengan bukan Muslim mengupas beberapa permasalahan fiqh yang berkaitan dengan cara berinteraksi orang Islam dengan orang bukan Islam. Memandangkan buku tersebut diolah untuk bacaan umum, maka pengarang cuba membawa permasalahan fiqh dalam bentuk mudah dan kurang menekankan aspek perbandingan mazhab dan dalil. Antara topik yang menjadi fokus pengarang ialah hukum berinteraksi dengan bukan Islam dalam menyambut perayaan, berjiran, makanan, kenajisan anjing dan khinzir, arak, perkahwinan dan politik. Namun masih banyak aspek kekeluargaan yang tidak dibincangkan seperti hak penjagaan anak, nasab anak, hak perwarisan dan pengurusan jenazah antara Muslim dengan bukan Muslim.

Menurut Chandra (1990), kontroversi kaum di Malaysia boleh dibahagikan kepada beberapa fasa. Pada tahun 1950-an, isu kewarganegaraan dan kontrak sosial mendominasi hubungan kaum, diikuti dengan isu bahasa pada tahun 1960-an sebelum pelaksanaan Dasar Ekonomi Baru (DEB), manakala kuota dan urbanisasi mencorakkan hubungan etnik pada tahun 1970-an dan 1980-an.

Pada tahun 1990-an dan milenium, isu-isu agama begitu kuat mempengaruhi hubungan etnik di negara ini. Menurut beliau lagi, jika dibandingkan isu-isu dalam hubungan kaum di Malaysia sejak lima dasawarsa lalu, isu agama yang muncul sejak akhir-akhir ini begitu kritikal impaknya. Pandangan ini disokong oleh Syed Husin Ali (2008) yang menyifatkan sentimen hubungan etnik pada masa kini berada pada tahap tinggi yang boleh menyebabkan konflik dan pertumpahan darah.

Terdapat segelintir masyarakat kurang memahami konsep hidup kebersamaan dalam sesebuah negara yang terdiri dari pelbagai agama, etnik dan budaya. Hal ini terjadi adalah disebabkan kebimbangan sesetengah masyarakat ialah apabila berlakunya interaksi antara pelbagai agama, etnik dan budaya, ia akan mempengaruhi mereka untuk berubah dari sudut agama dan kepercayaan mereka. Tambahan pula, sebahagian masyarakat kurang selesa dengan adanya sindiran sosial atau wujud perasaan tidak senang dalam kalangan penganut agama yang sama sehingga ada yang mempersoalkan ketulenan iman seseorang terhadap agamanya jika mereka berbaik-baik dan berinteraksi dengan penganut agama yang berlainan (Nasruddin Yunos, et. al. 2018, Tamadun Islam dan Tamadun Asia, Bangi: Pusat Citra Universiti).

Hal ini dibuktikan dengan kenyataan yang dikeluarkan oleh Perdana Menteri Malaysia, Tun Dr. Mahathir Mohamad dalam satu sidang akhbar yang dibuat. Beliau merayu agar media lebih bertanggungjawab dan tidak menghasilkan laporan yang boleh memburukkan lagi keadaan perkauman di negara ini. Beliau, yang juga Pengerusi Pakatan Harapan berkata, memang wujud tindakan segelintir pihak yang cuba mengapi-apikan sentimen perkauman di negara ini, namun media juga harus memainkan peranan dalam memastikan perkara itu tidak berlarutan. Menjelaskan lebih lanjut, Dr Mahathir berkata, rakyat Malaysia harus mengambil iktibar tentang api permusuhan antara kaum yang terjadi di luar negara (Astroawani, 2019).

Menurut Shamsul Amri (2010), antara masalah yang dihadapi oleh Malaysia pada ketika ini bersangkut paut kepada kesilapan meletakkan persamaan apabila menyatakan perpaduan sosial itu sama dengan perpaduan ekonomi. Sifat-sifat utama perpaduan gagal difahami dan tidak disentuh, antaranya elemen asimilasi, akomodasi, akulturasi dan amalgamasi. Andaian sering diberi jika pembahagian kek ekonomi seperti yang dirancang melalui DEB berhasil, maka secara automatik Malaysia mampu mencapai perpaduan bersifat nasional. Namun, hasilnya tidak seperti yang diharapkan. Perpaduan nasional telah ditafsirkan dengan fahaman sempit dan berubah menjadi satu bentuk pertandingan untuk merebut hak milik ekonomi. Dan isu ini menjalar menjadi 'perebutan nasional' antara kelompok etnik. 
Dalam pada itu, antara punca ketidakfahaman mengenai kebersamaan hidup di Malaysia adalah disebabkan oleh berlaku isu-isu yang dianggap sensitif dalam kalangan masyarakat di Malaysia. Dewasa ini, senario yang berlaku di Malaysia mengenai isu hubungan kaum sedang hangat diperkatakan. Hal ini dikatakan demikian kerana isu tersebut dilihat menyumbang kepada persepsi yang kurang disenangi oleh sebahagian masyarakat Islam termasuk pihak berkuasa agama seolah-olah menggambarkan sesetengah pihak termasuk pemimpin-pemimpin politik kurang menitik beratkan persoalan yang berkaitan prinsip yang perlu diamalkan dalam hubungan antara kaum dan agama.

Tambahan pula, menurut Khairul Azhar et al. (2013) yang mengatakan bahawa antara permasalahan dakwah orang Islam terhadap bukan Islam yang berlaku dalam negara ini antaranya kebimbangan melampau terhadap pengaruh agama lain dan kecelaruan memahami ritual dan budaya agama lain.

Suasana tersebut menimbulkan kecelaruan dalam kalangan masyarakat Islam terhadap konsep hubungan kaum dan agama, adakah ia dibenarkan di dalam Islam, adakah perbuatan demikian menggambarkan sikap toleransi beragama, adakah adat dalam agama-agama berlainan dianggap sebagai amalan agama dan beberapa persoalan lain timbul. Kesemua ini memerlukan suatu jawapan yang utuh dalam konteks Islam agar masyarakat mempunyai sikap dan pendirian yang jelas dari sudut prinsip dan amalannya. Persoalannya ialah, adakah ianya boleh dibenarkan begitu sahaja di atas konsep kebebasan beragama? Justeru masyarakat Islam perlu merujuk kepada pihak yang berautoriti seperti mufti dan jawatankuasa fatwa dalam perkara yang berkaitan demikian (Wan Zulkifli et. 2016).

Kekeliruan sebenarnya berpunca daripada kejahilan terhadap perbezaan antara agama lain dengan Islam itu sendiri. Ini berkaitan dengan kefahaman yang rendah dalam kalangan masyarakat tentang ilmu perbandingan agama. Kesannya, dua bentuk ekstremisme berlaku dalam beragama sama ada individu itu sebagai Islam yang liberal dalam segala aspek pergaulan dengan agama lain termasuk akidah antara yang menjadi polemik semasa ialah mengenai pluralisme agama (Nazneen et al., 2018).

Antara permasalahan yang berlaku dalam kalangan masyarakat adalah kurang menitik beratkan tentang persaudaraan atas dasar kemanusiaan. Mereka agak janggal dan kurang selesa untuk memberi bantuan dan mengeratkan persaudaraan jika berlainan etnik, bangsa dan agama. Al-Qaradhawi (1987) menegaskan, jika masalah ini tidak di atasi, ia akan menyebabkan lahirnya pelbagai bentuk pertentangan dan permusuhan dalam kalangan mereka sama ada dari sudut perbalahan politik, konflik antara agama dendam-mendendam antara satu sama lain sehingga menghalang keharmonian dalam kehidupan bermasyarakat, memecahbelahkan persaudaraan antara satu sama lain dalam sebuah masyarakat dan negara.

Sejarah telah membuktikan terdapat beberapa konflik antara etnik telah berlaku di Malaysia antaranya, Peristiwa 13 Mei 1969 (Parker,1979:1) akibat daripada sikap tidak puas hati dari sudut agihan kekayaan negara, Peristiwa Kampung Medan pada Mac 2001 (Muhamad Kamarul \& Zaharah, 2005:109) akibat sikap tidak boleh bertolak ansur apabila berlaku pertembungan kepentingan antara dua pihak yang melibatkan hal ehwal agama yang memberi kesan yang agak kritikal (Utusan Malaysia, 26 November 2006), Peristiwa Kampung Rawa pada 1998 (Muhamad Kamarul \& Zaharah, 2005:109) diakibatkan oleh sikap tidak menghormati amalan agama etnik lain.

Laporan Jabatan Perpaduan Negara dan Integrasi Nasional, terdapat 327 kes berkaitan dengan konflik sosial berlaku di Malaysia dari tahun 1996 - 2002. Berdasarkan jumlah tersebut, 81 kes berkaitan pergaduhan antara etnik, 76 kes berkaitan politik, 65 kes berkaitan agama, 38 kes berkaitan keselamatan dan selebihnya ialah berkaitan konflik sosial seperti masalah kejiranan, pendidikan dan sebagainya.

Salah satu bentuk ekstremisme lagi ialah individu itu sebagai Islam yang begitu rigid terhadap bukan Islam. Dalam erti kata lain, seseorang Muslim itu lebih selesa dengan kehidupannya itu yang hidup dalam negara majoriti Muslim seperti Malaysia namun dalam masa yang sama kerisauan untuk bergaul dengan bukan Islam di sekelilingnya (Nazneen et al., 2018). 
Selain itu, terdapat juga sebahagian masyarakat Malaysia yang mempunyai sikap rigid dengan amalan satu mazhab. Kadang-kadang ia akan menyebabkan kesulitan dalam berurusan dengan masyarakat bukan Islam. Hal ini dikatakan demikian kerana dalam kehidupan bermasyarakat, masyarakat Islam tidak dapat mengelak daripada berurusan dengan manusia yang lain termasuk dari kalangan bukan Islam.

\section{Metod Kajian}

Kajian ini akan dilaksanakan berdasarkan soal selidik secara atas talian (online) dalam kalangan responden yang pernah didedahkan tentang nilai interaksi sebenar seramai 554 orang responden. Kajian yang dijalankan ini merupakan kajian tinjauan dengan menggunakan pendekatan kaedah kuantitatif. Borang soal selidik digunakan sebagai instrumen kajian bagi mengukur tahap pengamalan nilai-nilai ketamadunan berdasarkan kursus tersebut. Pengkaji memilih untuk menggunakan skala persetujuan Likert lima mata untuk mengukur item soal selidik dalam kajian ini iaitu:(1) Sangat Tidak Setuju, (2) Tidak Setuju, (3) Tidak Pasti, (4) Setuju dan (5) Sangat Setuju. Soal selidik ini menggambarkan ukuran perspektif responden yang merupakan responden yang pernah didedahkan dengan mengenai ilmu peradaban di Malaysia. Menurut Cohen et al. (2007) skala Likert ini sesuai digunakan bagi mengukur pandangan yang diberikan tentang sesuatu amalan, persepsi dan sikap.

Hasil kajian dan analisis yang telah dibuat mampu mengetahui taburan kekerapan, adakah responden pernah mempelajari nilai peradaban sebelum mereka hadir ke peringkat universiti. Adakah dengan mempelajari kursus ini, mereka mampu menerapkan nilai-nilai interaksi yang baik dalam diri mereka dan bagaimana mereka menerapkan nilai-nilai tersebut dalam kehidupan mereka. Hal ini penting supaya mereka agar pengetahuan dan pemahaman yang betul dan tepat mengenai peradaban mampu diterapkan dalam kehidupan mereka.

Data yang dipungut dianalisis dan dikodkan secara kuantitatif dengan menggunakan teknik SPSS terhadap soal selidik yang dijawab oleh pelajar. Ini membolehkan pengkaji memahami dengan lebih mendalam terhadap isu yang dikaji.

Analisis juga dilakukan dengan menentukan teori/hipotesis daripada data yang dikumpulkan (grounded theory). Begitu juga mencari maklumat yang tersirat dalam teks (discourse analysis), analisis ke atas petunjuk seperti perkataan, bahasa badan dan sebagainya (semiotic) dan pemahaman ke atas perspektif/pandangan dan pengalaman seseorang individu atau pelajar (interpretative phenomenological experience).

\section{Hasil Kajian}

Berdasarkan kaji selidik yang dijalankan, penulis mendapati majoriti pelajar bahkan hampir kesemuanya menunjukkan bahawa mereka mampu menerapkan nilai-nilai yang baik dalam mewujudkan suasana jaringan sosial yang lebih harmoni di Malaysia. Item-item bagi nilai keharmonian akan diulas dengan lebih lanjut berdasarkan jadual-jadual berikut.

\section{Profil responden}

Kesemua data daripada Google FormsApp telah dimasukkan ke dalam SPSS untuk dijadikan pangkalan data utama. Kemudian, semakan dibuat untuk menyingkirkan responden yang tidak menjawab melebihi $10 \%$ jumlah keseluruhan soalan. Maka responden akhir kajian ini adalah seramai 554 orang daripada 556 orang yang terlibat, iaitu pengurangan hanya 2 orang responden. Frekuensi jantina responden menunjukkan, lelaki seramai 139 orang (25.1 peratus) dan perempuan 415 orang (74.9 peratus). Bilangan responden perempuan melebihi responden lelaki boleh dianggap normal dalam universiti awam. Ringkasan jantina dalam dilihat seperti dalam Jadual 1. 
DOI: https://doi.org/10.47405/mjssh.v6i7.919

Jadual 1: Taburan Jantina Responden

\begin{tabular}{lrr}
\hline Jantina & Frekuensi & Peratus \\
\hline lelaki & 139 & 25.1 \\
perempuan & 415 & 74.9 \\
Jumlah & 554 & 100.0 \\
\hline
\end{tabular}

Majoriti responden adalah berumur 20 tahun (50.7 peratus). Ini diikuti oleh responden berumur 21 tahun ( 37.5 peratus), berumur 22 tahun (6.5 peratus), berumur 23 tahun (1.8 peratus), berumur 19 tahun (1.1 peratus), berumur 24 tahun ( 0.7 peratus), berumur 25,26 dan 28 masing-masing 0.4 peratus. Manakala responden yang tidak menjawab soalan ini adalah 3 orang ( 0.5 peratus). Jadual 2 menunjukkan ringkasan taburan umur responden.

Jadual 2: Taburan Umur Responden

\begin{tabular}{lrr}
\hline Umur & Frekuensi & Peratus \\
\hline 19.00 & 6 & 1.1 \\
20.00 & 281 & 50.7 \\
21.00 & 208 & 37.5 \\
22.00 & 36 & 6.5 \\
23.00 & 10 & 1.8 \\
24.00 & 4 & 0.7 \\
25.00 & 2 & 0.4 \\
26.00 & 2 & 0.4 \\
28.00 & 2 & 0.4 \\
Data yang hilang & 3 & 0.5 \\
Jumlah & 554 & 100.0 \\
\hline
\end{tabular}

Majoriti responden adalah daripada aliran sekolah menengah kebangsaan (58.1 peratus). Seterusnya sekolah menengah agama (17.9 peratus) dan lain-lain aliran (23.6 peratus). Manakala terdapat 2 responden tidak menjawab soalan ini ( 0.4 peratus). Ringkasan aliran responden dapat dilihat seperti dalam Jadual 3.

Jadual 3: Taburan Aliran Sekolah Responden

\begin{tabular}{lrr}
\hline Aliran & Frekuensi & Peratus \\
\hline SMKA & 99 & 17.9 \\
SMK & 322 & 58.1 \\
lain-lain & 131 & 23.6 \\
Jumlah yang dikira & 552 & 99.6 \\
Data yang hilang & 2 & 0.4 \\
Jumlah keseluruhan & 554 & 100.0 \\
\hline
\end{tabular}

Ringkasan latar belakang demografi responden yang berbeza dari segi jantina, umur, fakulti dan aliran sekolah ini dapat dilihat seperti dalam Jadual 4.

Jadual 4: Demografi Responden

\begin{tabular}{llcc}
\hline & Demografi Responden & \multicolumn{2}{c}{ Taburan Responden } \\
\cline { 3 - 4 } Jantina & Lelaki & N & \% \\
& Perempuan & 139 & 25.1 \\
& & 415 & 74.9
\end{tabular}


DOI: https://doi.org/10.47405/mjssh.v6i7.919

\begin{tabular}{clcc} 
Umur & $19-20$ & 287 & 51.8 \\
& $21-22$ & 244 & 44.0 \\
& $23-24$ & 10 & 2.5 \\
& $25-26$ & 4 & 0.8 \\
& $27-28$ & 4 & 0.8 \\
\multirow{4}{*}{ Aliran } & Data yang hilang & 3 & 0.5 \\
& SMKA & 99 & 17.9 \\
& SMK & 322 & 58.1 \\
& Lain-lain & 131 & 23.6 \\
& Data yang hilang & 2 & 0.4 \\
\hline
\end{tabular}

\section{Kesahan Data}

Kesahan data kajian adalah perkara pertama yang perlu difikirkan untuk memilih instrumen kajian (Fraenkel \& Wallen, 1996). Data yang bersih kemudiannya telah diuji dengan Ujian Faktor Analisis (factor analysis) dan Ujian Kebolehpercayaan (reliability) untuk memastikan kesesuaian item mengikut objektif kajian dan nilai kebolehpercayaan item sebelum analisis selanjutnya diteruskan.

\section{Ujian Faktor Analisis}

Dengan meneliti item-item soal selidik, didapati tiga pemboleh ubah utama dilabelkan sebagai Nilai Interaksi, Amalan dan Cabaran, rujuk Jadual 5. Manakala ringkasan item-item adalah seperti dalam Jadual 6.

Jadual 5: Output Analisis Faktor

\begin{tabular}{|c|c|c|c|c|}
\hline & \multicolumn{3}{|c|}{ Komponen } & \\
\hline & 1 & 2 & & \\
\hline M & .516 & & & \\
\hline $\mathrm{N}$ & .513 & & & \\
\hline $\mathrm{R}$ & .366 & & & \\
\hline Y & .366 & & & \\
\hline $\mathrm{AB}$ & .436 & & & \\
\hline AI & .320 & & & \\
\hline $\mathrm{AO}$ & .534 & & & \\
\hline $\mathrm{AR}$ & .511 & & & \\
\hline $\mathrm{AU}$ & .557 & & & \\
\hline $\mathrm{AV}$ & .521 & & & \\
\hline AY & .462 & & & \\
\hline $\mathrm{AF}$ & & & .337 & \\
\hline AP & & & .510 & \\
\hline $\mathrm{AX}$ & & & .420 & \\
\hline $\mathrm{P}$ & & & & .333 \\
\hline $\mathrm{T}$ & & & & .414 \\
\hline V & & & & .354 \\
\hline $\mathrm{AA}$ & & & & .434 \\
\hline $\mathrm{AD}$ & & & & .515 \\
\hline $\mathrm{AE}$ & & & & .489 \\
\hline $\mathrm{AK}$ & & & & .304 \\
\hline $\mathrm{AQ}$ & & & & .546 \\
\hline
\end{tabular}

Kaedah ekstrak: Principal Component Analysis.

Kaedah putaran: Varimax dengan Kaiser Normalization. 
DOI: https://doi.org/10.47405/mjssh.v6i7.919

Jadual 6: Item-item Penerapan Nilai Harmoni dalam Hubungan Etnik

\begin{tabular}{|c|c|c|c|}
\hline \multicolumn{4}{|c|}{ Petunjuk } \\
\hline Bil & Simbol & Item & Faktor? \\
\hline 1 & M & $\begin{array}{l}\text { Saya suka apabila ada orang di sekeliling saya meskipun dari } \\
\text { pelbagai bangsa }\end{array}$ & Nilai Interaksi \\
\hline 2 & $\mathrm{~N}$ & $\begin{array}{l}\text { Kadangkala bila saya membaca berita pembunuhan di sesebuah } \\
\text { negara dan melihat kedaifan mereka, saya merasa sedih dan } \\
\text { hiba }\end{array}$ & Nilai Interaksi \\
\hline 3 & $\mathrm{R}$ & $\begin{array}{l}\text { Tanpa mempunyai pegangan agama yang kuat, hidup ini tidak } \\
\text { menarik bagi saya }\end{array}$ & Nilai Interaksi \\
\hline 4 & Y & $\begin{array}{l}\text { Apabila saya dihina, saya cuba hanya untuk memaafkan dan } \\
\text { melupakannya }\end{array}$ & Nilai Interaksi \\
\hline 5 & $\mathrm{AB}$ & Saya selalu inginkan negara yang aman dan harmoni & Nilai Interaksi \\
\hline 6 & $\mathrm{AC}$ & $\begin{array}{l}\text { Saya seronok menyelesaikan masalah kawan saya meskipun } \\
\text { berlainan bangsa }\end{array}$ & Nilai Interaksi \\
\hline 7 & AI & $\begin{array}{l}\text { Saya percaya perbezaan idea mengenai perkara benar dan salah } \\
\text { dalam sesuatu masyarakat bersifat relatif dan diterima dalam } \\
\text { masyarakat tersebut }\end{array}$ & Nilai Interaksi \\
\hline 8 & $\mathrm{AO}$ & $\begin{array}{l}\text { Saya bersimpati ke atas orang-orang lain yang kurang bernasib } \\
\text { baik dari saya meskipun berlainan agama, kaum dan etnik }\end{array}$ & Nilai Interaksi \\
\hline 9 & AR & Saya cenderung untuk bertanggapan baik terhadap orang lain & Nilai Interaksi \\
\hline 10 & AY & Saya berpandukan idea keagamaan dalam perilaku saya & Nilai Interaksi \\
\hline 11 & AU & Saya menghargai warisan negara & Nilai Interaksi \\
\hline 12 & $\mathrm{AV}$ & Saya menghormati agama rasmi negara & Nilai Interaksi \\
\hline 13 & $\mathrm{AF}$ & $\begin{array}{l}\text { Saya merasakan mampu untuk mengendalikan emosi saya } \\
\text { apabila berhadapan perselisihan pandangan antara etnik } \\
\text { berlainan }\end{array}$ & Amalan \\
\hline 14 & AP & Saya sering berinteraksi dengan kawan etnik lain & Amalan \\
\hline 15 & $\mathrm{AX}$ & Saya gemar makan makanan di kedai mamak & Amalan \\
\hline 16 & $\mathrm{P}$ & $\begin{array}{l}\text { Saya nampaknya tidak akan berupaya untuk menjadikan diri } \\
\text { saya berada sebilik/seperumahan dengan bangsa lain }\end{array}$ & Cabaran \\
\hline 17 & $\mathrm{~T}$ & $\begin{array}{l}\text { Ada orang berpendapat, saya seorang yang bersikap dingin dan } \\
\text { terlalu berkira dengan kawan-kawan dari etnik lain }\end{array}$ & Cabaran \\
\hline 18 & V & $\begin{array}{l}\text { Apabila saya berinteraksi dengan bangsa lain, saya selalu } \\
\text { merasa kurang selesa }\end{array}$ & Cabaran \\
\hline 19 & AA & $\begin{array}{l}\text { Saya mempunyai masalah dalam menahan kemarahan saya } \\
\text { terhadap bangsa dan etnik lain }\end{array}$ & Cabaran \\
\hline 20 & $\mathrm{AD}$ & $\begin{array}{l}\text { Saya lebih baik dari kebanyakan orang lain dan saya tahu } \\
\text { hakikat tersebut }\end{array}$ & Cabaran \\
\hline 21 & $\mathrm{AE}$ & $\begin{array}{l}\text { Saya adalah individu yang produktif yang sentiasa berusaha } \\
\text { menyumbangkannya kepada kemajuan negara }\end{array}$ & Cabaran \\
\hline 22 & AK & $\begin{array}{l}\text { Saya hanya percaya apa-apa maklumat antarabangsa melalui } \\
\text { television sahaja }\end{array}$ & Cabaran \\
\hline 23 & $\mathrm{AQ}$ & Saya seorang yang lebih hebat dari orang lain & Cabaran \\
\hline
\end{tabular}

\section{Ujian Kebolehpercayaan}

Kebolehpercayaan data kajian adalah konsistensi dalaman yang dimiliki oleh item yang digunakan dalam sesebuah kajian (Creswell, 2005). Konsistensi ini merujuk kepada sejauh mana skor setiap item berhubung antara satu sama lain. Keputusan yang diperoleh daripada ujian kebolehpercayaan (reliability) item menunjukkan kesemua pemboleh ubah mempunyai nilai Alpha Cronbach (a) yang sangat baik. Walaupun nilai bagi Amalan adalah rendah namun nilai ini hanya disandarkan kepada bilangan 3 soalan sahaja. Hal ini mengesahkan bahawa semua pemboleh ubah ini mempunyai nilai kebolehpercayaan yang boleh diterima dan digunakan untuk menjalankan analisis selanjutnya. Jadual 
DOI: https://doi.org/10.47405/mjssh.v6i7.919

7 di bawah menunjukkan nilai Alpha Cronbach (a) bagi semua pemboleh ubah yang digunakan dalam kajian ini.

Jadual 7: Dapatan Ujian Kebolehpercayaan

\begin{tabular}{lcc}
\multicolumn{1}{c}{ Faktor } & Pekali Kebolehpercayaan & Bilangan Item \\
\hline Nilai interaksi & .833 & 12 \\
Amalan & .453 & 3 \\
Cabaran & .587 & 8 \\
\hline
\end{tabular}

\section{Perbincangan}

Generasi sekarang merupakan generasi yang lahir pada sekitar tahun 1980-2000an, sudah menunjukkan terdapatnya gejala kecelaruan pemikiran dan sikap. Gaya hidup hedonisme, kebebasan yang tanpa batas, serta hilangnya etika di media sosial adalah serangkaian contoh dari kecelaruan tersebut. Rhenald (2018) menyebut generasi sekarang sebagai generasi strawberi, yang digambarkan sebagai generasi yang menarik, namun rapuh kerana tidak memiliki kekuatan mentaliti dan pemikiran serta nilai-nilai yang utuh dalam menghadapi cabaran masa kini. Berdasarkan kepada hasil kajian mengenai penerapan nilai interaksi dalam kalangan responden, secara keseluruhannya berada pada tahap sangat tinggi. Ini memperlihatkan bahawa pemahaman responden tentang nilai interaksi yang sebenar mampu melahirkan kehidupan yang harmoni dalam kalangan masyarakat yang terdiri dari pelbagai etnik. Perbincangan seterusnya akan membuktikan dengan lebih lanjut berkenaan item-item dalam Nilai Interaksi, Amalan dan Cabarannya.

\section{Nilai Interaksi}

\section{Suka dikelilingi pelbagai bangsa}

Seterusnya, kajian juga menunjukkan 276 responden (49.8 peratus) bersetuju bahawa mereka suka dikelilingi pelbagai bangsa. Manakala 136 responden (24.5 peratus) sangat bersetuju, diikuti 120 responden (21.7 peratus) neutral, 19 responden (3.4 peratus) mengatakan tak setuju dan seorang responden ( 0.2 peratus) sangat tak setuju. Lihat Jadual 8.

Jadual 8: Suka dikelilingi pelbagai bangsa

\begin{tabular}{lcc}
\hline & Frekuensi & Peratus \\
\hline Sangat Tak Setuju & 1 & .2 \\
Tak Setuju & 19 & 3.4 \\
Neutral & 120 & 21.7 \\
Bersetuju & 276 & 49.8 \\
Sangat Bersetuju & 136 & 24.5 \\
Jumlah yang dikira & 552 & 99.6 \\
Data yang hilang & 2 & .4 \\
Jumlah keseluruhan & 554 & 100.0 \\
\hline
\end{tabular}

\section{Sedih dan hiba melihat pembunuhan dan kedaifan di negara lain}

Selain itu, kajian mendapati 267 responden (48.2 peratus) bersetuju bahawa mereka sedih dan hiba melihat pembunuhan dan kedaifan di negara lain dan 237 responden (42.8 peratus) pula sangat bersetuju. Seterusnya, hanya 38 responden (6.9 peratus) bersikap neutral, 5 responden ( 0.9 peratus) tak bersetuju dan 4 responden ( 0.7 peratus) sangat tak setuju. Jadual 9 menunjukkan ringkasan tersebut.

Jadual 9: Sedih dan hiba melihat pembunuhan dan kedaifan di negara lain 
DOI: https://doi.org/10.47405/mjssh.v6i7.919

\begin{tabular}{lcc}
\hline & Frekuensi & Peratus \\
\hline Sangat Tak Setuju & 4 & .7 \\
Tak Setuju & 5 & .9 \\
Neutral & 38 & 6.9 \\
Bersetuju & 267 & 48.2 \\
Sangat Bersetuju & 237 & 42.8 \\
Jumlah yang dikira & 551 & 99.5 \\
Data yang hilang & 3 & .5 \\
Jumlah keseluruhan & 554 & 100.0 \\
\hline
\end{tabular}

\section{Pegangan agama yang kuat}

Kajian mendapati 204 responden (36.8 peratus) bersetuju bahawa mereka mempunyai pegangan agama yang kuat dalam diri. Manakala 191 responden (34.5 peratus) sangat bersetuju, diikuti neutral 113 responden (20.4 peratus), 34 responden (6.1 peratus) tak setuju dan 10 responden (1.8 peratus) sangat tak setuju. Ringkasan ini dapat dilihat dalam Jadual 10.

Jadual 10: Pegangan agama yang kuat

\begin{tabular}{lcc} 
& Frekuensi & Peratus \\
\hline Sangat Tak Setuju & 10 & 1.8 \\
Tak Setuju & 34 & 6.1 \\
Neutral & 113 & 20.4 \\
Bersetuju & 204 & 36.8 \\
Sangat Bersetuju & 191 & 34.5 \\
Jumlah yang dikira & 552 & 99.6 \\
Data yang hilang & 2 & .4 \\
Jumlah keseluruhan & 554 & 100.0 \\
\hline
\end{tabular}

\section{Bersikap pemaaf}

Kajian mendapati 215 responden (38.8 peratus) bersikap neutral dalam bersikap pemaaf, diikuti 202 responden (36.5 peratus) bersetuju, 72 responden (13.0 peratus) tak setuju, 46 responden ( 8.3 peratus) sangat bersetuju dan 18 responden (3.2 peratus) mengatakan sangat tak setuju. Rujuk Jadual 11.

Jadual 11: Bersikap pemaaf

\begin{tabular}{lcc}
\hline & Frekuensi & Peratus \\
\hline Sangat Tak Setuju & 18 & 3.2 \\
Tak Setuju & 72 & 13.0 \\
Neutral & 215 & 38.8 \\
Bersetuju & 202 & 36.5 \\
Sangat Bersetuju & 46 & 8.3 \\
Jumlah yang dikira & 553 & 99.8 \\
Data yang hilang & 1 & .2 \\
Jumlah keseluruhan & 554 & 100.0 \\
\hline
\end{tabular}

\section{Inginkan negara yang aman harmoni}

Kajian juga mendapati majoriti responden iaitu 408 responden (73.6 peratus) sangat bersetuju bahawa mereka inginkan negara yang aman harmoni. Diikuti 133 responden (24.0 peratus) bersetuju, diikuti neutral 7 responden ( 1.3 peratus) dan masing-masing seorang responden ( 0.2 peratus) tak setuju dan sangat tak setuju. Rujuk Jadual 12. 
Jadual 12: Inginkan negara yang aman harmoni

\begin{tabular}{lcc}
\hline & Frekuensi & Peratus \\
\hline Sangat Tak Setuju & 1 & .2 \\
Tak Setuju & 1 & .2 \\
Neutral & 7 & 1.3 \\
Bersetuju & 133 & 24.0 \\
Sangat Bersetuju & 408 & 73.6 \\
Jumlah yang dikira & 550 & 99.3 \\
Data yang hilang & 4 & .7 \\
Jumlah keseluruhan & 554 & 100.0 \\
\hline
\end{tabular}

\section{Seronok menyelesaikan masalah kawan berlainan bangsa.}

Kajian mendapati 268 responden (48.4 peratus) bersetuju bahawa mereka seronok dapat menyelesaikan masalah kawan berlainan bangsa. Manakala 184 responden (33.2 peratus) sangat bersetuju, diikuti neutral 88 responden (15.9 peratus), 9 responden (1.6 peratus) tak setuju dan seorang responden (0.2 peratus) sangat tak setuju. Rujuk Jadual 13.

Jadual 13: Seronok menyelesaikan masalah kawan berlainan bangsa

\begin{tabular}{lcc}
\hline & Frekuensi & Peratus \\
\hline Sangat Tak Setuju & 1 & .2 \\
Tak Setuju & 9 & 1.6 \\
Neutral & 88 & 15.9 \\
Bersetuju & 268 & 48.4 \\
Sangat Bersetuju & 184 & 33.2 \\
Jumlah yang dikira & 550 & 99.3 \\
Data yang hilang & 4 & .7 \\
Jumlah keseluruhan & 554 & 100.0 \\
\hline
\end{tabular}

\section{Boleh menerima perbezaan agama}

Seterusnya, seramai 260 responden (46.9 peratus) bersikap neutral bahawa mereka boleh menerima perbezaan agama, diikuti 250 responden (45.1 peratus) bersetuju, 36 responden (6.5 peratus) sangat bersetuju, 5 responden ( 0.9 peratus) tak setuju dan 3 responden ( 0.5 peratus) sangat tak setuju. Rujuk Jadual 14.

Jadual 14: Boleh menerima perbezaan agama

\begin{tabular}{lcc}
\hline & Frekuensi & Peratus \\
\hline Sangat Tak Setuju & 3 & .5 \\
Tak Setuju & 5 & .9 \\
Neutral & 260 & 46.9 \\
Bersetuju & 250 & 45.1 \\
Sangat Bersetuju & 36 & 6.5 \\
Jumlah keseluruhan & 554 & 100.0 \\
\hline
\end{tabular}

\section{Simpati terhadap bangsa, agama dan etnik lain}

Kajian mendapati 274 responden (49.5 peratus) bersetuju bahawa mereka simpati terhadap bangsa, agama dan etnik lain. Manakala 236 responden (42.6 peratus) sangat bersetuju, diikuti 34 responden (6.1 peratus) bersikap neutral, 5 responden ( 0.9 peratus) tak setuju dan 3 responden ( 0.5 peratus) sangat tak setuju. Rujuk Jadual 15. 
DOI: https://doi.org/10.47405/mjssh.v6i7.919

Jadual 15: Simpati terhadap bangsa, agama dan etnik lain

\begin{tabular}{lcc} 
& Frekuensi & Peratus \\
\hline Sangat Tak Setuju & 3 & .5 \\
Tak Setuju & 5 & .9 \\
Neutral & 34 & 6.1 \\
Bersetuju & 274 & 49.5 \\
Sangat Bersetuju & 236 & 42.6 \\
Jumlah yang dikira & 552 & 99.6 \\
Data yang hilang & 2 & .4 \\
Jumlah keseluruhan & 554 & 100.0 \\
\hline
\end{tabular}

\section{Berfikiran positif terhadap orang lain}

Kajian seterusnya mendapati 259 responden (46.8 peratus) bersetuju bahawa mereka berfikiran positif terhadap orang lain. Manakala 195 responden (35.2 peratus) bersikap neutral, 81 responden (14.6 peratus) sangat bersetuju, 17 responden (3.1 peratus) tak setuju dan 2 responden ( 0.4 peratus) sangat tak setuju. Rujuk Jadual 16.

Jadual 16: Berfikiran positif terhadap orang lain

\begin{tabular}{lll}
\hline & Frekuensi & Peratus \\
\hline Sangat Tak Setuju & 2 & .4 \\
Tak Setuju & 17 & 3.1 \\
Neutral & 195 & 35.2 \\
Bersetuju & 259 & 46.8 \\
Sangat Bersetuju & 81 & 14.6 \\
Total & 554 & 100.0 \\
\hline
\end{tabular}

\section{Mengikut kehendak agama dalam perilaku}

Kajian mendapati 258 responden (46.6 peratus) bersetuju bahawa mereka akan mengikuti kehendak agama dalam perilaku. Manakala 112 responden (20.4 peratus) sangat bersetuju, diikuti 169 responden (30.5 peratus) bersikap neutral dan 14 responden (2.5 peratus) tak setuju. Rujuk Jadual 17.

Jadual 17: Mengikuti kehendak agama dalam perilaku

\begin{tabular}{lcc}
\hline & Frekuensi & Peratus \\
\hline Tak Setuju & 14 & 2.5 \\
Neutral & 169 & 30.5 \\
Bersetuju & 258 & 46.6 \\
Sangat Bersetuju & 112 & 20.2 \\
Jumlah yang dikira & 553 & 99.8 \\
Data yang hilang & 1 & .2 \\
Jumlah keseluruhan & 554 & 100.0 \\
\hline
\end{tabular}

\section{Menghargai warisan}

Kajian mendapati 315 responden (56.9 peratus) bersetuju bahawa mereka menghargai warisan. Manakala 163 responden (29.4 peratus) sangat bersetuju, diikuti 67 responden (12.1 peratus) bersikap neutral dan masing-masing 4 responden ( 0.7 peratus) tak setuju dan sangat tak setuju. Rujuk Jadual 18. 
DOI: https://doi.org/10.47405/mjssh.v6i7.919

Jadual 18: Menghargai warisan

\begin{tabular}{lcc} 
& Frekuensi & Peratus \\
\hline Sangat Tak Setuju & 4 & .7 \\
Tak Setuju & 4 & .7 \\
Neutral & 67 & 12.1 \\
Bersetuju & 315 & 56.9 \\
Sangat Bersetuju & 163 & 29.4 \\
Jumlah yang dikira & 553 & 99.8 \\
Data yang hilang & 1 & .2 \\
Jumlah keseluruhan & 554 & 100.0 \\
\hline
\end{tabular}

\section{Menghormati agama rasmi negara}

Kajian mendapati majoriti responden iaitu 327 responden (59.0 peratus) sangat bersetuju bahawa mereka menghormati agama rasmi negara. Diikuti 188 responden (33.9 peratus) bersetuju, 34 responden (6.1 peratus) bersikap neutral dan seorang responden ( 0.2 peratus) sangat tak setuju. Rujuk Jadual 19.

Jadual 19: Menghormati agama rasmi negara

\begin{tabular}{lcc}
\hline & Frekuensi & Peratus \\
\hline Sangat Tak Setuju & 1 & .2 \\
Neutral & 34 & 6.1 \\
Bersetuju & 188 & 33.9 \\
Sangat Bersetuju & 327 & 59.0 \\
Jumlah Yang Dikira & 550 & 99.3 \\
Data yang hilang & 4 & .7 \\
Jumlah keseluruhan & 554 & 100.0 \\
\hline
\end{tabular}

\section{Amalan}

\section{Mampu mengawal emosi apabila berselisih pandangan dengan etnik lain}

Kajian mendapati 299 responden (54.0 peratus) bersetuju bahawa mereka mampu mengawal emosi apabila berselisih pandangan dengan etnik lain. Manakala 180 responden (32.5 peratus) bersikap neutral, 63 responden (11.4 peratus) sangat bersetuju, 8 responden (1.4 peratus) tak setuju dan seorang responden (0.2 peratus) sangat tak setuju. Rujuk Jadual 20.

Jadual 20: Mampu mengawal emosi apabila berselisih pandangan dengan etnik lain

\begin{tabular}{lcc}
\hline & Frekuensi & Peratus \\
\hline Sangat Tak Setuju & 1 & .2 \\
Tak Setuju & 8 & 1.4 \\
Neutral & 180 & 32.5 \\
Bersetuju & 299 & 54.0 \\
Sangat Bersetuju & 63 & 11.4 \\
Jumlah yang dikira & 551 & 99.5 \\
Data yang hilang & 3 & .5 \\
Jumlah keseluruhan & 554 & 100.0 \\
\hline
\end{tabular}




\section{Sering berinteraksi dengan kawan dari etnik lain}

Kajian mendapati 241 responden (43.5 peratus) bersetuju bahawa mereka sering berinteraksi dengan kawan dari etnik lain. Manakala 176 responden (31.8 peratus) bersikap neutral, 114 responden (20.6) sangat bersetuju, 16 responden ( 2.9 peratus) tak setuju dan 4 responden ( 0.7 peratus) sangat tak setuju. Rujuk Jadual 21.

Jadual 21: Sering berinteraksi dengan kawan dari etnik lain

\begin{tabular}{lcc}
\hline & Frekuensi & Peratus \\
\hline Sangat Tak Setuju & 4 & .7 \\
Tak Setuju & 16 & 2.9 \\
Neutral & 176 & 31.8 \\
Bersetuju & 241 & 43.5 \\
Sangat Bersetuju & 114 & 20.6 \\
Jumlah yang dikira & 551 & 99.5 \\
Data yang hilang & 3 & .5 \\
Jumlah keseluruhan & 554 & 100.0 \\
\hline
\end{tabular}

\section{Gemar makan di kedai mamak}

Kajian mendapati 202 responden (36.5 peratus) bersikap neutral bahawa mereka gemar makan di kedai mamak. Diikuti 163 responden (29.4 peratus) bersetuju, 78 responden (14.1 peratus) tak setuju, 70 responden (12.6 peratus) sangat bersetuju dan 41 responden ( 7.4 peratus) sangat tak setuju. Rujuk Jadual 22.

Jadual 22: Gemar makan di kedai mamak

\begin{tabular}{lcc}
\hline & Frekuensi & Peratus \\
\hline Sangat Tak Setuju & 41 & 7.4 \\
Tak Setuju & 78 & 14.1 \\
Neutral & 202 & 36.5 \\
Bersetuju & 163 & 29.4 \\
Sangat Bersetuju & 70 & 12.6 \\
Jumlah keseluruhan & 554 & 100.0 \\
\hline
\end{tabular}

\section{Cabaran}

\section{Tidak berupaya untuk berada sebilik/ seperumahan dengan bangsa lain}

Kajian mendapati 214 responden (38.6 peratus) bersikap neutral bahawa mereka tidak berupaya untuk berada sebilik atau seperumahan dengan bangsa lain. Manakala 166 responden (30.0 peratus) tak setuju, masing-masing 74 responden (13.4 peratus) bersetuju dan sangat tak setuju, dan 23 responden (4.2 peratus) sangat bersetuju. Rujuk Jadual 23.

Jadual 23: Tidak berupaya untuk berada sebilik/seperumahan dengan bangsa lain

\begin{tabular}{lcc}
\hline & Frekuensi & Peratus \\
\hline Sangat Tak Setuju & 74 & 13.4 \\
Tak Setuju & 166 & 30.0 \\
Neutral & 214 & 38.6 \\
Bersetuju & 74 & 13.4 \\
Sangat Bersetuju & 23 & 4.2 \\
Jumlah yang dikira & 551 & 99.5
\end{tabular}


Data yang hilang

Jumlah keseluruhan

554

\section{Bersikap dingin dan terlalu berkira dengan kawan dari etnik lain}

Kajian mendapati 276 responden (49.8 peratus) tak setuju bahawa mereka bersikap dingin dan terlalu berkira dengan kawan dari etnik lain. Manakala 131 responden (23.6 peratus) sangat tak setuju, 117 responden (21.1 peratus) bersikap neutral, 27 responden (4.9 peratus) bersetuju dan 2 responden (0.4 peratus) sangat bersetuju. Rujuk Jadual 24.

Jadual 24: Bersikap dingin dan terlalu berkira dengan kawan dari etnik lain

\begin{tabular}{lcc} 
& Frekuensi & Peratus \\
\hline Sangat Tak Setuju & 131 & 23.6 \\
Tak Setuju & 276 & 49.8 \\
Neutral & 117 & 21.1 \\
Bersetuju & 27 & 4.9 \\
Sangat Bersetuju & 2 & .4 \\
Jumlah yang dikira & 553 & 99.8 \\
Data yang hilang & 1 & .2 \\
Jumlah keseluruhan & 554 & 100.0 \\
\hline
\end{tabular}

\section{Tidak selesa berinteraksi dengan bangsa lain}

Kajian mendapati 255 responden (46.0 peratus) tak setuju bahawa mereka tidak selesa berinteraksi dengan bangsa lain. Manakala 134 responden (24.2 peratus) bersikap neutral, 118 responden (21.3 peratus) sangat tak setuju, 42 responden ( 7.6 peratus) bersetuju dan 2 responden ( 0.4 peratus) sangat bersetuju. Rujuk Jadual 25.

Jadual 25: Tidak selesa berinteraksi dengan bangsa lain

\begin{tabular}{lcc} 
& Frekuensi & Peratus \\
\hline Sangat Tak Setuju & 118 & 21.3 \\
Tak Setuju & 255 & 46.0 \\
Neutral & 134 & 24.2 \\
Bersetuju & 42 & 7.6 \\
Sangat Bersetuju & 2 & .4 \\
Jumlah Yang Dikira & 551 & 99.5 \\
Data yang hilang & 3 & .5 \\
Jumlah keseluruhan & 554 & 100.0 \\
\hline
\end{tabular}

\section{Sukar menahan marah terhadap bangsa dan etnik lain}

Kajian mendapati 283 responden (51.1 peratus) tak setuju bahawa mereka sukar menahan marah terhadap bangsa dan etnik lain. Manakala 142 responden (25.6 peratus) sangat tak setuju, 107 responden (19.3 peratus) bersikap neutral, 19 responden (3.4 peratus) bersetuju dan 3 responden $(0.5$ peratus) sangat tak bersetuju. Rujuk Jadual 26.

Jadual 26: Sukar menahan marah terhadap bangsa dan etnik lain

\begin{tabular}{lcc}
\hline & Frekuensi & Peratus \\
\hline Sangat Tak Setuju & 142 & 25.6 \\
Tak Setuju & 283 & 51.1 \\
Neutral & 107 & 19.3 \\
Bersetuju & 19 & 3.4
\end{tabular}


Sangat Bersetuju

\section{Merasa diri lebih baik daripada orang lain}

Kajian mendapati 277 responden (50.0 peratus) bersikap neutral bahawa mereka merasa diri lebih baik daripada orang lain. Manakala 145 responden (26.2 peratus) tak setuju, 68 responden (12.3 peratus) bersetuju, 45 responden (8.1 peratus) sangat tak setuju dan 16 responden (2.9 peratus) sangat bersetuju. Rujuk Jadual 27.

Jadual 27: Merasa diri lebih baik daripada orang lain

\begin{tabular}{lcc}
\hline & Frekuensi & Peratus \\
\hline Sangat Tak Setuju & 45 & 8.1 \\
Tak Setuju & 145 & 26.2 \\
Neutral & 277 & 50.0 \\
Bersetuju & 68 & 12.3 \\
Sangat Bersetuju & 16 & 2.9 \\
Jumlah yang dikira & 552 & 99.6 \\
Data yang hilang & 2 & .4 \\
Jumlah keseluruhan & 554 & 100.0 \\
\hline
\end{tabular}

\section{Merasa produktif dan sentiasa berusaha menyumbang kepada kemajuan negara}

Kajian mendapati 262 responden (47.3 peratus) bersikap neutral dalam merasa diri mereka produktif dan sentiasa berusaha menyumbang kepada kemajuan negara. Manakala 208 responden (37.5 peratus) bersetuju, 46 responden ( 8.3 peratus) sangat bersetuju, 36 responden (6.5 peratus) tak setuju dan 2 responden (0.4 peratus) sangat tak setuju. Rujuk Jadual 28.

Jadual 28:Merasa produktif dan sentiasa berusaha menyumbang kepada kemajuan negara

\begin{tabular}{lcc} 
& Frekuensi & Peratus \\
\hline Sangat Tak Setuju & 2 & .4 \\
Tak Setuju & 36 & 6.5 \\
Neutral & 262 & 47.3 \\
Bersetuju & 208 & 37.5 \\
Sangat Bersetuju & 46 & 8.3 \\
Jumlah keseluruhan & 554 & 100.0 \\
\hline
\end{tabular}

\section{Percaya maklumat antarabangsa melalui televisyen sahaja}

Kajian mendapati 270 responden (48.7 peratus) tak setuju bahawa mereka percaya maklumat antarabangsa melalui televisyen sahaja. Manakala 151 responden (27.3 peratus) bersikap neutral, 99 responden (17.9 peratus) sangat tak setuju, 27 responden (4.9 peratus) bersetuju dan 6 responden (1.1 peratus) sangat bersetuju. Rujuk Jadual 29.

Jadual 29: Percaya maklumat antarabangsa melalui televisyen sahaja

\begin{tabular}{lcc}
\hline & Frekuensi & Peratus \\
\hline Sangat Tak Setuju & 99 & 17.9 \\
Tak Setuju & 270 & 48.7 \\
Neutral & 151 & 27.3 \\
Bersetuju & 27 & 4.9 \\
Sangat Bersetuju & 6 & 1.1 \\
Jumlah yang dikira & 553 & 99.8 \\
Data yang hilang & 1 & .2
\end{tabular}




\section{Merasa diri lebih hebat daripada orang lain}

Kajian mendapati 243 responden (43.9 peratus) bersikap neutral bahawa mereka merasa diri lebih hebat daripada orang lain. Manakala 166 responden (30.0 peratus) tak setuju, 89 responden (16.1 peratus) sangat tak setuju, 43 responden ( 7.8 peratus) bersetuju dan 11 responden ( 2.0 peratus) sangat bersetuju. Rujuk Jadual 30.

Jadual 30: Merasa diri lebih hebat daripada orang lain

\begin{tabular}{lcc}
\hline & Frekuensi & Peratus \\
\hline Sangat Tak Setuju & 89 & 16.1 \\
Tak Setuju & 166 & 30.0 \\
Neutral & 243 & 43.9 \\
Bersetuju & 43 & 7.8 \\
Sangat Bersetuju & 11 & 2.0 \\
Jumlah yang dikira & 552 & 99.6 \\
Data yang hilang & 2 & .4 \\
Jumlah keseluruhan & 554 & 100.0 \\
\hline
\end{tabular}

\section{Perbincangan}

Dapatan ini secara umumnya selari dengan nilai dan amalan interaksi yang sebenar dalam menghadapi pelbagai cabaran pada masakini bagi mewujudkan kehidupan yang harmoni di Malaysia. Ia bukan sahaja melibat responden Melayu beragama Islam yang mengamalkan nilai interaksi yang berteraskan Islam dan Melayu, tetapi turut memperlihatkan responden yang bukan Islam yang terdiri dalam kalangan pelbagai etnik sama ada berbangsa Cina ataupun India, mereka dilihat mampu mengamalkan nilai interaksi yang baik berdasarkan kepercayaan dana adat mereka.

Analisis bagi setiap item dalam pelbagai dimensi nilai interaksi dan amalannya mengukuhkan lagi penemuan kajian ini. Ini lebih jelas dapatan menunjukkan hampir semua item menggambarkan skor min penghayatan nilai interaksi dan amalannya yang tinggi. Antaranya ialah nilai pegangan agama yang kuat boleh memandu mereka dalam mewujudkan interaksi yang antara sesama manusia, nilai simpati terhadap orang lain meskipun berlainan bangsa, etnik dan agama, sifat pemaaf, mempunyai persepsi positif terhadap orang lain, sikap toleransi dengan kaum yang lain, sayangkan keharmonian dalam sesebuah negara dan hormat nilai warisan dan agama rasmi negara. Fenomena ini menunjukkan, nilai interaksi dan amalannya menunjukkan penghayatan yang tinggi oleh para responden.

Dapatan kajian dilihat selari dengan saranan yang dikemukakan oleh ajaran agama terutama Islam. Dalam agama Islam, berinteraksi dengan bukan Muslim, ada beberapa prinsip yang wajar diberi perhatian berdasarkan al-Quran dan al-Sunnah. Di sana terdapat formula syariah yang berkaitan pendirian mengenai persefahaman, pergaulan hidup dengan masyarakat bukan Muslim dan hubungan dengan kepelbagaian etnik dan negara lain.

Berdasarkan dapatan kajian penulis, majoriti responden memahami dan mampu mengamalkan konsep hidup kebersamaan atau Fiq al-Ta'asyusy dalam Bahasa Arab yang merujuk kepada orang Islam dan orang bukan Islam tinggal bersama dalam sebuah negara. Hidup kebersamaan ini tidak akan wujud melainkan mempunyai sikap bersopan santun dan berbudi. Kehidupan seumpama ini tidak berhasil melainkan wujud saling memahami, ingin membina jaringan sosial antara satu sama lain dalam tradisinya dikenali sebagai ahl al-dhimmah tetapi sekarang dikenali sebagai al-muwatinun iaitu warga negara atau pun orang Islam tinggal bersama dengan orang yang datang meminta perlindungan dengan pemerintah umat Islam secara aman dengan sistem al-ta'syirah. 
Manakala menurut pandangan Sheikh Hussein Ali Mustapha (2014) konsep نعايش merujuk kepada Islam sebagai agama universal yang membawa mesej kepada semua umat manusia, iaitu mesej yang memerintahkan keadilan dan melarang ketidakadilan dan meletakkan asas bagi keamanan di muka bumi, dan menyeru kepada kehidupan bersama yang positif dalam kalangan semua manusia dalam suasana persaudaraan dan toleransi dalam kalangan semua rakyat tanpa mengira bangsa, warna kulit dan kepercayaan

Selain itu, dapatan kajian mendapati majoriti responden terutama yang beragama Islam dilihat mempunyai pegangan agama yang utuh dan mereka mampu menyerap dalam kehidupan berinteraksi dengan masyarakat pelbagai etnik dan agama. Oleh itu, bagi mereka selagi mana amalan dan adat yang tidak menyalahi akidah Islam dan ajaran Islam adalah tidak dilarang kepada umat Islam. Hal ini dapat mewujudkan toleransi. Namun begitu toleransi atau bertolak ansur agama Islam terhadap agama, amalan dan budaya masyarakat bukan Islam tidak bersifat fleksibel dalam segala-segala-galanya tanpa merujuk kepada prinsip akidah dan konsep halal dan haram dalam syariat Islam.

Oleh sebab itu Islam tidak boleh bertolak ansur jika prinsip-prinsip dalam agama Islam dicabuli oleh mana-mana pihak serta perlu memahami konsep kebebasan beragama sebagaimana yang terdapat dalam Perlembagaan Persekutuan. Hal ini dilihat selari dengan dapatan kajian penulis yang menyatakan bahawa majoriti responden memahami tentang agama rasmi yang termaktub dalam Perlembagaan persekutuan.

Dapatan kajian ini juga hampir selaras dengan penemuan kajian yang dinyatakan oleh Uthman ElMuhammady (2010) yang menyatakan bahawa tokoh agama dalam kalangan bukan Islam seperti Dalai Lama sendiri menggambarkan toleransi agama tidak bermaksud mencampur adukkan antara agama-agama tetapi menghormati antara satu sama lain. Ini kerana dalam dapatan kajian penulis, majoriti berpendapat bahawa mereka percaya perbezaan idea mengenai perkara benar dan salah dalam sesuatu masyarakat bersifat relatif dan diterima dalam masyarakat tersebut.

Dapatan kajian juga dilihat membuktikan bahawa majoriti responden terutama beragama Islam meneladani apa yang yang telah dilakukan Rasulullah SAW dalam melaksanakan hubungan antara individu dan masyarakatnya atas dasar kemanusiaan yang mampu merentasi perbezaan agama, etnik, warna kulit dan status serta jauh dari sikap prejudis, stereotaip dan diskriminasi antara sesama manusia (Hani al-Mubarak \& Syauqi, 1997). Dari sudut kemanusiaan, dapatan kajian penulis mendapati majoriti responden memahami tentang banyak perkara yang dianggap boleh bertoleransi antara penganut Islam dan masyarakat bukan Islam. Ia berkait rapat dengan penghormatan nilai-nilai kemanusiaan bukannya menerapkan nilai-nilai penyamarataan dari sudut akidah dan agama. Apa yang diamalkan oleh responden adalah mereka dilihat tidak menunjukkan apa-apa reaksi yang negatif terhadap penganut agama lain atau mempunyai perbezaan etnik dan bangsa. Bahkan mereka sanggup menghulurkan bantuan atas dasar kemanusiaan kepada mereka yang memerlukan meskipun berbeza dari sudut agama, bangsa, etnik dan budaya.

Dapatan kajian juga mendapati bahawa majoriti responden khususnya yang beragama Islam memahami dan cenderung ke arah mewujudkan persepsi dan tanggapan yang baik terhadap sesama manusia termasuk mereka yang berlainan agama, bangsa atau etnik. Ia selari dengan pandangan alKarim (1988) yang menyebut tentang keterbukaan Islam terhadap kebebasan beragama dengan batas sempadan yang tidak menegangkan hubungan dalam masyarakat berbagai agama. Selain itu, Islam tidak menghalang penganut agama lain mendirikan rumah ibadat mereka. Kebenaran ini adalah bergantung pada jenis kawasan yang didiami.

\section{Kesimpulan}

Kajian ini berjaya membuktikan sejauh mana masyarakat mampu menerapkan nilai interaksi dalam kehidupan bermasyarakat yang mempunyai kepelbagaian agama, etnik dan budaya. Ini kerana kajian ini mengguna pakai instrumen yang dibangunkan untuk mengenal pasti pengetahuan, dan kefahaman 
mereka terhadap kefahaman nilai interaksi bagi mewujudkan keharmonian hubungan etnik dalam masyarakat di Malaysia.

Dengan adanya data dalam penyelidikan yang dijalankan ini, masyarakat akan mendapat suatu panduan tentang kefahaman nilai interaksi yang baik dalam mewujudkan keharmonian hubungan etnik di Malaysia khususnya dalam bidang sosial. Ia sekali gus dapat mengenal pasti permasalahan sebenar masyarakat Islam yang boleh menggugat keharmonian hidup bermasyarakat dalam berinteraksi dengan masyarakat pelbagai agama, etnik dan budaya.

Nilai interaksi merupakan aspek penting dalam membentuk sikap dan karakter dalam diri seseorang. Nilai interaksi ditunjangi dengan sifat seperti pegangan agama yang kuat, bersangka baik terhadap orang lain, bersimpati, suka tolong-menolong, mencintai toleransi dan kedamaian, berlemah lembut dan sebagainya. Nilai-nilai interaksi ini dapat diintegrasikan dalam pengekalan hubungan baik sesama manusia tanpa mengira bangsa, agama dan budaya dalam masyarakat. Dalam menghadapi arus pemodenan, berlakunya perubahan sikap dan karakter seseorang yang menerima inovasi teknologi yang dibawa oleh perkembangan masyarakat masa kini. Rentetan itu, usaha untuk memperkukuhkan nilai-nilai interaksi dalam budaya pelbagai etnik di Malaysia harus dilakukan dengan mengambil kira nilai-nilai Islam seiring dengan perkembangan masyarakat moden. Kemajuan teknologi dan penerapan nilai-nilai interaksi sebenar di Malaysia perlu seiringan dan tidak boleh diabaikan bagi mengekalkan keharmonian etnik. Kesedaran di kalangan masyarakat pelbagai etnik ini penting bagi mewujudkan sebuah negara yang bukan sahaja maju dalam teknologi malah dalam kemajuan bangsa itu sendiri yang mana kedua-dua ini adalah asas dalam perkembangan tamadun manusia.

\section{Rujukan}

Abd al-Karim Zaydan. (1988). Ahkam al-dhimiyyah wa al-Musta'min fi Dar al-Islam, Beirut: Muassasah al-Risalah.

Abdul Ghafar Haji Don et al. (2009). Dakwah kepada Non-Muslim di Malaysia: Konsep, Metode dan Pengalaman, al-Hikmah (Journal of Islamic Dakwah, Bangi: Fakulti Pengajian Islam, UKM, alQaradawi Yusof. 2001, Fi Fiqh al-Aqalliyat al-Muslimah. Dar al-Syurouk.

Astroawani (2019). Isu Perkauman: Media Jangan Burukkan Lagi Keadaan - Tun Mahathir, Dalam Laman Web Astro Awani, Http://Www.Astroawani.Com/Berita-Malaysia/Isu-Perkauman-MediaJangan-Burukkan-Lagi-Keadaan-Tun-Mahathir-216367.

Hani al-Mubarak \& Syawqi Abu Khalil. al-Islam wa al-Tafahum wa al-Ta'ayusy bayna al-Syu'ub, Beirut: Dar al-Fikr alMu'asir.

Khairul Azhar Meerangani \& Rushdi Ramli. (2016). Isu Penggunaan Kalimah Allah oleh Pihak Kristian: Analisis Menurut Hukum Islam. Jurnal Fiqh 13: 117-138.

Mohammad Nidzam Abd. Kadir (2009). Fiqah Berinteraksi dengan Non-Muslim, Kuala Lumpur Telaga Biru.

Muhamad Kamarul Kabilan \& Zaharah Hasan (ed.), (2005), Readings on Ethnic Relations in a Multicultural Society, Serdang : Fakulti Pengajian Pendidikan, UPM

Nasruddin Yunos et. al. (2018). Tamadun Islam dan Tamadun Asia, Bangi: Pusat Citra Universiti

Nazneen Binti Ismail et al. (2018). Pendekatan Fiqh Ta'ayusy dalam Menangani Konflik Antara Agama, dalam Jurnal ISLAMIYYAT 40(2) 2018: 151 - 16

Osman Abdullah@Chuah Hock Leng \& Abdul Salam Muhamad Shukri. (2008). Muslim Converts in Malaysia: The Problem of Cultural Adjustment, International Islamic University Malaysia

Parker, W C. (1979), Communication and The May 13th Crisis A Psychoculutral Interpretation, Kuala Lumpur : Penerbit Universiti Malaya

Shamsul Amri Baharuddin (2010). Dasar Ekonomi Baru (DEB) Dan Implikasi Terhadap Hubungan Etnik Di Malaysia", wacana anjuran Jabatan Pengajian Islam dan Kemanusiaan, Pusat Bahasa dan Pembangunan Insan, Universiti Teknikal Malaysia Melaka. Lihat lama Web, http://alahkam.net/home/index. $\quad$ php?option=com_content\&view=article\&id=53 25:dasarekonomi-baru-dan-implikasi-terhadaphubungan-etnik. 
DOI: https://doi.org/10.47405/mjssh.v6i7.919

Sheikh Hussein Ali Mustapha. (2014). Fiqh Al-Ta'ayush Fi Sirah alNabawiyah. Lubnan: Markaz Islami' al-Saqafi

Uthman El-Muhammady. (2010). Beberapa Isu Dalam Pluralisme Agama- Satu Pengamatan Ringkas dalam, Wacana Membanteras Pluralisme Agama dan Pemurtadan Umat anjuran Pertubuhan Muafakat Sejahtera Masyarakat Malaysia (MUAFAKAT), JAKIM, JAIS, ACCIN dan Permuafakatan NGO WP di Dewan Serbaguna, Masjid Wilayah Persekutuan, Kuala lumpur, pada 14hb Disember 2010.

Wan Zulkifli, Et. (2016), Maqasid Syariah Dalam Pembinaan Fatwa Berkaitan Amalan Rentas Agama Dan Rentas Budaya Di Malaysia. Al-Hikmah Journal of Islamic Dakwah, Bangi: Fakulti Pengajian Islam, 8(2).

Yusri Mohamad. 2010. Ancaman Pluralisme Agama di Malaysia: Satu Tinjauan Awal, dalam, Wacana Membanteras Pluralisme Agama dan Pemurtadan Umat anjuran Pertubuhan Muafakat Sejahtera Masyarakat Malaysia (MUAFAKAT), JAKIM, JAIS, ACCIN dan Permuafakatan NGO WP di Dewan Serbaguna, Masjid Wilayah Persekutuan, Kuala lumpur, pada 14hb Disember 2010. 